\section{Not just for Christmas}

Stephen Hancocks OBE
Send your comments to the

Editor-in-Chief,

British Dental Journal

64 Wimpole Street,

London

W1G 8YS

Email bdj@bda.org
I know, I know, it is still 'only' November and so it is far too early to be thinking about Christmas. But if the benefits of maturity count for anything then one observation is that those people who tut and complain when shops begin stocking yuletide fare in August are those same souls who, come 12 December, are tearing out their hair because they haven't yet bought any cards, let alone asked when the last posting date is in order for them to arrive in time. And, unfortunately the years are now passing faster. I know this for a fact as March was only just over seven weeks ago.

The phrase 'not just for Christmas' came to prominence some years ago as part of a campaign to emphasise that having a pet (usually in relation to a dog) was not only for the excitement of the unveiling on Christmas morning but that it was a commitment from then on, for the whole year round. The same should be true of our attitude to charity, to which the saying must also have resonance. Charity is classically described as beginning at home and the two charities featured in an article in this issue (pages 435-437) are perfect examples of this approach. The BDA Benevolent Fund was started over 130 years ago, at or about the same time as the BDA itself, and has been run and administered by dentists, for dentists ever since. Our Victorian forbears had great vision in collectively initiating a service to their own community then, and our community now, which cares for and supports those who through no fault of their own suffer as a result of misfortune.

The second charity is the Dentists' Health Support Trust, which runs the eponymous Programme aimed at helping and supporting dentists and now DCPs who have problems with addiction and/or mental health issues. Similarly, this was created by dentists for dentists and possibly partially as a result, enjoys the most remarkable rehabilitation rate for those it helps, a rate far and away higher than equivalent organisations run within society as a whole.

\section{TOUGH ECONOMIC TIMES}

Other parallels exist between the two. Currently, as with many charities and projects funded by contributions and donations, the financial downturn leads to a double problem. While income drops as potential donors give less, or cease to give at all, the need for the care that the money can help to provide climbs as steeply. Distress is more keenly felt as times get harder and so the equation falls further from balance. Less coming in, more going out.
The Ben Fund in particular has historically used the season of goodwill to hold until recently its annual giant raffle but latterly to launch an appeal to members of the BDA in particular, but also the profession in general; the Fund serves dentists and their families across the board, not only BDA members. But here is the theme again, in these difficult times, these two organisations, so deserving of our contributions, need help now, yes, but not just at Christmas - year round too.

One of my undisputedly favourite books is Charles Dickens' A Christmas Carol. If ever there is a story, the morals of which one can carry equally for twelve months, then this is surely it. I freely admit that on many occasions as I am about to hurry past a collection box or a Big Issue seller on the pretext of being too busy to stop or convincing myself that I have no change, I recall Scrooge wishing to the Spirit that he had given a coin to the boy singing a carol through the icy keyhole of his counting house the previous day instead of seizing a ruler to ward the youngster off. The thought of it arrests me regularly and I ask you too to select your own conscience-pricking example in consideration of supporting 'our' charities. I know that we too are increasingly being faced by our own double problems: a decline in patient numbers who are starting to spend less discretionary money on oral health, and a rise in our cost of living. The impetus is therefore to give less, not more, but I ask you to simultaneously consider how relatively fortunate the majority of us still are and how even a small, ongoing contribution can make a major difference to others less well placed.

In the business premises of Scrooge and Marley, the two portly men who arrive on Christmas Eve seeking additions to their charitable fund ask how much Ebenezer wishes to be 'put down for'. 'Nothing' comes the tart reply. 'You wish to remain anonymous?' they query. 'I wish to be left alone. Since you ask me what I wish, that is my answer.' I know that you would prefer to be left alone too, and not have me remind you. We all would at this time of year and probably at others too, but I am sorry that I cannot allow it; our colleagues - like them, loath them, pretend they are not there, attempt to close your mind to them - need my help, your help, our help. Please do it now but please also reflect that it is not just for Christmas.

DOI: 10.1038/sj.bdj.2011.913 